\title{
A case of cardio renal syndrome
}

\author{
*Vishrut Joshi ${ }^{1}$, Devdeep Mukherjee ${ }^{1}$, Agnisekhar Saha ${ }^{2}$, Md Shakil Akhtar $^{1}$ \\ Sri Lanka Journal of Child Health, 2017; 46(2): 175-177 \\ DOI: http://dx.doi.org/10.4038/sljch.v46i2.8277 \\ (Key words: Cardio renal syndrome, congestive cardiac failure, acute kidney injury, renin-angiotensin-aldosterone \\ system, ventricular septal defect)
}

\section{Introduction \\ Cardio renal syndrome (CRS) is the simultaneous dysfunction of both heart and kidney ${ }^{1}$. The primary organ involved may be the heart or kidney, resulting in either acute or chronic secondary dysfunction of the other organ ${ }^{2,3}$. Based on the primary failing organ and chronicity, CRS can be divided into 5 types ${ }^{4,5}$.}

\section{Case Report}

A one year and 2 month old boy, a known case of tiny atrial septal defect (ASD) with $7 \mathrm{~mm}$ ventricular septal defect (VSD), receiving furosemide and enalapril for the last 1 year, was admitted with a history of low grade fever for 7 days. He also had swelling of both legs for 4 days and reduced urine output for 2 days before admission. On examination, the child weighed $7.5 \mathrm{~kg}$ and was irritable. He had pallor, bilateral pedal oedema and facial puffiness. He had a respiratory rate of 54/min and a heart rate of $193 / \mathrm{min}$ with a gallop rhythm. His blood pressure was $60 / 42 \mathrm{~mm} \mathrm{Hg}$ and he was maintaining an oxygen saturation of $86 \%$ in room air. A grade 4 systolic murmur was heard on auscultation of the chest. On abdominal examination, the liver was palpable $5 \mathrm{~cm}$ below the right costal margin.

Investigations prior to admission included a haemoglobin level of $6.5 \mathrm{~g} / \mathrm{dl}$, a total white cell count of $18,500 / \mathrm{cu} \mathrm{mm}$ ( $72 \%$ neutrophils), a C-reactive protein of $52.5 \mathrm{mg} / \mathrm{L}$ and urine microscopy showing 15-20 red cells and a field full of pus cells. Investigations on the first day of admission included a haemoglobin level of $4.8 \mathrm{~g} / \mathrm{dl}$, a total white cell count of $19,600 / \mathrm{cu} \mathrm{mm} \mathrm{(72 \%} \mathrm{neutrophils),} \mathrm{a} \mathrm{platelet} \mathrm{count}$

${ }^{1}$ Institute of Child Health, Kolkata, India, ${ }^{2}$ Fortis Hospitals, Kolkata, India

*Correspondence: vishrutjoshi@ymail.com

(Received on 02 February 2016: Accepted after revision on 17 March 2016)

The authors declare that there are no conflicts of interest

Personal funding was used for this project.

Open Access Article published under the Creative Commons Attribution CC-BY (C) (P) of $548,000 / \mathrm{cu} \mathrm{mm}$, a C-reactive protein of $72 \mathrm{mg} / \mathrm{L}$, a blood urea of $194 \mathrm{mg} / \mathrm{dl}$, a serum creatinine of $3.94 \mathrm{mg} / \mathrm{dl}$, a serum sodium of $135 \mathrm{mEq} / \mathrm{L}$, a serum potassium of $7.4 \mathrm{mEq} / \mathrm{L}$, a serum calcium of $6.3 \mathrm{mg} / \mathrm{dl}$ and urine microscopy showing a field full of red cells and pus cells.

Arterial blood gas analysis was suggestive of metabolic acidosis $(\mathrm{pH} \mathrm{7.12}$, bicarbonate $16 \mathrm{mEq} / \mathrm{L}$, pCO2 $56 \mathrm{mmHg}$, base excess $-18 \mathrm{mEq} / \mathrm{L}$ ). Chest $\mathrm{x}$-ray was suggestive of cardiomegaly. Ultrasonography of abdomen showed features suggestive of renal parenchymal disease. The child had features of congestive cardiac failure and acute kidney injury (AKI) with sepsis.

Initially the patient was managed with calcium gluconate, nebulization with salbutamol (for hyperkalaemia), bicarbonate correction (for acidosis), furosemide and normal saline bolus (for AKI) and correction of hypocalcaemia. Urine microscopy revealed a field full of pus cells. Meropenem was started in a renal adjusted dose. Anaemia was treated with packed red cells. Enalapril was withheld. Intake, output, electrolytes and renal function were strictly monitored. However, the child continued to have reduced urine output and persistent metabolic acidosis for which furosemide infusion was started. Bicarbonate and calcium corrections were continued. Patient showed further clinical deterioration on day 3 of admission with increase in respiratory distress and oxygen requirement. Urine output was $0.3 \mathrm{ml} / \mathrm{kg} / \mathrm{hr}$. Urine culture revealed growth of $\mathrm{E}$. coli and meropenem was continued. Patient did not show significant clinical improvement after 4 days. Peritoneal dialysis was started on day 5 of admission with monitoring of renal function. Patient showed significant clinical and biochemical improvement from day 5 to 8 of admission. Dialysis was stopped after 36 cycles with progressive improvement in renal function and gradual increase in urine output to $1.4 \mathrm{ml} / \mathrm{kg} / \mathrm{hr}$. Clinical deterioration started again on day 12 of admission, following discontinuation of furosemide with increase in respiratory distress, increasing bilateral pedal edema and facial puffiness. He had to be ventilated for congestive cardiac failure. 
With gradual improvement, the patient was extubated on day 19 of admission. On discharge, the blood urea was $129 \mathrm{mg} / \mathrm{dl}$, the serum creatinine was $0.75 \mathrm{mg} / \mathrm{dl}$ and urine microscopy was normal. Patient was discharged on day 27 with oral furosemide, digoxin, aldactone, calcium and multivitamin with a diagnosis of tiny ASD, $7 \mathrm{~mm} \mathrm{VSD,} \mathrm{congestive} \mathrm{cardiac} \mathrm{failure,}$ $\mathrm{AKI}$ and urinary tract infection in a case of failure to thrive. He was operated for VSD 1 month later. At 1 year follow up he is growing well with no impairment in renal function. His primary cause of admission was cardio renal syndrome and the dilemma in management was whether to give fluids or to withhold them.

\section{Discussion}

Cardio renal syndrome (CRS) includes a variety of acute and chronic conditions where the primary failing organ can be either the heart or the kidney ${ }^{2,3}$. Our patient was a known case of tiny ASD and $7 \mathrm{~mm}$ VSD with ongoing sepsis and no documented previous renal dysfunction, making the heart the primary failing organ. At the time of admission patient was having both congestive cardiac failure and AKI, indicating secondary involvement of the kidney.

In a study by Erk $\mathrm{O}^{6}$, infection is among the most important precipitating factors in heart failure (38\% in systolic and $50 \%$ in diastolic heart failure). As our patient was having superimposed infection with a preexisting heart condition, it was the likely reason for the acute decompensation of heart function. Poor compliance-noncompliance to medicines is also a common cause of acute decompensated heart failure according to the study by Joseph SM, et $\mathrm{al}^{7}$. This was a contributory factor in our case.

Type 1 CRS is the one most commonly encountered in clinical practice ${ }^{8}$. In this type, acute heart failure or acutely decompensated chronic heart failure results in hypoperfusion secondary to poor cardiac output. Hypoperfusion of kidneys leads to activation of the renin-angiotensin-aldosterone system (RAAS), releasing angiotensin II and aldosterone into the circulation along with increase in endothelin 1 (a byproduct of increased angiotensin II levels). These result in water retention by reabsorption of sodium from the distal tubules. The net effect is an increase in pulmonary vascular congestion and worsening renal ischaemia that perpetuates RAAS activation ${ }^{4}$. Our patient was a known case of underlying heart disease for the last one year with acute decompensation, making him vulnerable to develop type 1 CRS.

Diuretics in higher doses or in combination aggravate AKI as an additional iatrogenic mechanism ${ }^{9,10}$. Our patient was on treatment with furosemide and enalapril for the last one year and was prone to develop renal dysfunction, as both loop diuretics and angiotensin converting enzyme inhibitors are also known to compromise renal function. Important consequence of CRS type 1 is decreased diuretic responsiveness, which occurs due to physiological phenomena of diuretic braking (decreasing magnitude of response to each administered dose of diuretic in congestive state) and post-diuretic sodium retention ${ }^{11,12}$. During the initial period we encountered similar problems as our patient did not show consistent response to diuretics until continuous diuretic infusion was started. Earlier use of slow high dose intravenous diuretics, dialysis with ultrafiltration for treatment of congestion, inotropes and left ventricular assistant device to maintain hemodynamics and maintain renal perfusion is the vital component for a short period of time, which is a clinical challenge of initial management ${ }^{9}$. While managing our patient in paediatric intensive care unit, we used continuous high dose diuretic infusion, peritoneal dialysis, decongestive drugs and inotropes.

\section{Acknowledgements}

Dr Rajiv Sinha, Associate Professor, Paediatric Nephrology gave valuable opinion regarding patient management.

\section{References}

1. Ronco C, Haapio M, House AA, Anavekar N, Bellomo R. Cardio-renal syndrome. Journal of the American College of Cardiology 2008; 52(19): 1527-39.

http://dx.doi.org/10.1016/j.jacc.2008.07.051 PMid: 19007588

2. Schrier RW. Cardio-renal versus renocardiac syndrome: Is there a difference? Nature Clinical Practice Nephrology 2007; 3(12):637.

http://dx.doi.org/10.1038/ncpneph0673

PMid: 18033224

3. Berl T, Henrich W. Kidney-heart interactions: epidemiology, pathogenesis, and treatment. Clinical Journal of the American Society of Nephrology 2006; 1:8 18.

http://dx.doi.org/10.2215/CJN.00730805

PMid: 17699186

4. Chan EJ, Dellsperger KC. Update on cardiorenal syndrome: A clinical conundrum. 
Advances in Peritoneal Dialysis 2011; 27:

82-6.

PMid: 22073835

5. Shah BN, Greaves K. The cardio-renal syndrome: A review. International Journal of Nephrology 2011; 2011: 11.

6. Erk O. Precipitating factors for systolic and diastolic heart failure: a four-year follow-up of 192 patients. Hong Kong Medical Journal 2004; 10(2):97-101.

PMid: 15075429

7. Joseph SM, Cedars AM, Ewald GA, et al. Acute decompensated heart failure. Texas Heart Institute Journal 2009; 36(6): 510-20. PMid: 20069075 PMCid: PMC2801958

8. Zaidi M, Rahman AJ, et al. Frequency of cardio-renal syndrome type-I in hospitalized children with acute heart failure in a tertiarycare hospital. Journal of the College of Physicians and Surgeons Pakistan 2014; 24(8): 577-80.

PMid: 25149838
9. Howard PA, Dunn MI. Aggressive diuresis for severe heart failure in the elderly. Chest 2001; 119:807-10.

http://dx.doi.org/10.1378/chest.119.3.807

10. Verma A, Solomon SD. Optimizing care of heart failure after acute MI with an aldosterone receptor antagonist. Current Heart Failure Reports 2007; 4:183-9. http://dx.doi.org/10.1007/s11897-007-00118

PMid: 18221614

11. Ellison DH. Diuretic resistance: physiology and therapeutics. Seminars in Nephrology 1999; 19:581-97.

PMid: 10598546

12. Almeshari K, Ahlstrom NG, Capraro FE, Wilcox CS. A volume independent component to post diuretic sodium retention in humans. Journal of the American Society of Nephrology 1993; 3:1878-83.

PMid: 8338919 